\title{
DINAMIKA PENGEMUDI ANGKOT KOTA MALANG DALAM ERA TRANSPORTASI BERBASIS ONLINE
}

\author{
Andhika Pratama ${ }^{1}$, Agus Purnomo ${ }^{1 *}$ \\ ${ }^{1}$ Universitas Negeri Malang, Indonesia \\ *e-mail: agus.purnomo.fis@um.ac.id
}

\begin{abstract}
Abstrak
Tujuan penelitian ini adalah untuk menelaah dinamika pengemudi angkot di Kota Malang dan mengetahui adaptasi mereka dalam menghadapi perkembangan transportasi online. Teknik pengumpulan data menggunakan observasi data kuantitatif dan wawancara secara snowball. Data yang dikumpulkan dianalisis dengan model interaktif yaitu Pengumpulan, Reduksi, Penyajian, dan Penarikan Kesimpulan. Hasil penelitian menunjukkan bahwa dinamika pengemudi angkot dipengaruhi oleh penurunan penghasilan yang signifikan. Terutama angkot yang melewati rute perbelanjaan modern dan kampus, sedangkan untuk angkot rute pasar tradisional dan area kota lama masih relatif stabil. Penurunan ini disebabkan angkot terdisrupsi oleh transportasi berbasis online. Pengemudi angkot memiliki dua strategi untuk menghadapi dinamika tersebut. Pertama, pengemudi angkot melakukan adaptasi dengan cara perbaikan fasilitas serta pelayanan. Kedua, tidak melakukan apapun dan menggantungkan pada takdir. Berbagai adaptasi perlu dilakukan agar angkot menjadi pilihan utama kembali. Peningkatan layanan dari pengemudi angkot menjadi penting untuk menjaga eksistensi moda transportasi ini. Oleh karena itu dukungan dari pemerintah dalam bentuk regulasi dan pinjaman dana lunak diperlukan sebagai katalisator program.
\end{abstract}

Kata kunci: Dinamika; Adaptasi; Pengemudi Angkot

\begin{abstract}
This study aims to examine the dynamics of public transportation drivers in Malang and find out their adaptation in facing the development of online transportation. The data collection technique used quantitative data observation and snowball interviews. The data collected were analyzed using an interactive model, namely, collection, reduction, presentation, and conclusion drawing. The results showed that a significant decrease influenced the dynamics of angkot drivers in income. Those that pass through modern shopping routes and campuses, while those for traditional market routes and the old town area, are still relatively stable. This decrease was due to the disruption of public transportation by online-based transportation. Angkot drivers have two strategies to deal with these dynamics. First, public transportation drivers make adaptations by improving facilities and services. Second, do nothing and rely on destiny. Various adaptations need to be made so that angkot becomes the primary choice again. Improved service from public transportation drivers is vital to maintain the existence of this mode of transportation. Therefore, the government's support in the form of regulations and soft loan funds is needed as a catalyst for the program.
\end{abstract}

Keywords: Dynamic; Adaptation; Angkot Drivers 


\section{PENDAHULUAN}

Perkembangan Teknologi, Informasi, dan Komunikasi (TIK) berdampak pada berbagai sektor, salah satunya adalah sektor industri. Adanya perkembangan TIK telah melahirkan banyak industri baru, seperti adanya industri handphone (Utami, 2010). Industri handphone terus mengalami perkembangan, pada awalnya produk handphone hanya digunakan untuk berkomunikasi melalui SMS dan menelfon, namun kini handphone dapat digunakan untuk mengakses informasi secara global (Muslimin, 2011). Pemerintah semakin menggalakkan peningkatan kualitas industri di bidang TIK, karena pada tahun 2009 dan 2010 dari sektor pengangkutan dan komunikasi berhasil mengalami pertumbuhan sebesar $15,5 \%$ serta $13,5 \%$ persen, sehingga dengan adanya industri TIK harapannya mampu meningkatkan perekonomian di Indonesia.

Perkembangan di bidang TIK juga berdampak pada industri transportasi, seperti adanya transportasi berbasis online. Moda transportasi ini menggunakan aplikasi dari perangkat selular, sebagai penghubung antara pengemudi dan penumpang, dengan tarif perjalanan yang sudah dapat dilihat pada aplikasi. Transportasi berbasis online, memanfaatkan kemajuan dibidang TIK untuk menyesuaikan kebutuhan masyarakat di era modern, sehingga semakin banyak ditemukan transportasi berbasis online. Perkembangannya seperti halnya yang terjadi di kota besar di Indonesia, seperti di Yogyakarta, keberadaannya sudah hampir mencapai 20.000 kendaraan, terdiri dari 8.000 mobil dan 12.000 sepeda motor (Rahayu, 2018).

Perkembangan transportasi online tersebut berdampak pada pengemudi transportasi konvesional. Keberadaanya armada transportasi berbasis online menyentuh angka ribuan, sebuah penelitian tahun 2017 tentang mode transportasi online dan transportasi konvensional memaparkan bahwa, kemunculan transportasi berbasis online menyebabkan transportasi konvensional menjadi termaginalkan (Anwar, 2017). Sebagai contoh yang terjadi di Kota Medan, keberadaan mode transportasi berbasis online, memberi pengaruh terhadap keberadaan angkot. Kini angkot hanya berjumlah sekitar 5.000 unit, dari 10.000 unit angkot yang sebelumnya beroperasi di kota (Sumut pos, 2018; Ticonuwu, 2018). Transportasi konvensional di kota Malang (pengemudi angkot) banyak melakukan adaptasi untuk bertahan dari gempuran transportasi online. Adaptasi yang dilakukan oleh pengemudi angkot diantaranya, untuk mendapatkan setoran dan penghasilan pengemudi angkot melaju dengan kecepatan tinggi dan sering tibatiba belok ke kanan dan kiri untuk memperoleh penumpang, kemudian pengemudi angkot juga menerapkan efisiensi kerja dengan memperhatikan waktu jadwal sekolah atau ibu-ibu ke pasar (Putranto, 2017). Optimalisasi untuk dapat memperoleh penghasilan yang maksimal juga dapat dilakukan dengan membagi shift kerja seperti yang dilakukan pada trayek $\mathrm{AH}$ Arjosari-Hamid Rusdi (Widyatami \& Achmad Dzulfiqar Alfiansyah, 2016).

Banyaknya penumpang angkot yang beralih ke transportasi online mengakibatkan banyak angkot yang tidak efektif. Analisis Load Factor menunjukan bahwa jumlah keberadaan armada angkot di Kota malang menunjukkan kelebihan jumlah kendaraan sebanyak $\pm 40 \%$ pada masing-masing trayek (Widyatami \& Achmad Dzulfiqar Alfiansyah, 2016). Kondisi tersebut mendorong terjadinya persaingan dalam mencari penumpang. Keterbatasan kemampuan pengemudi angkot dalam beradaptasi di era transportasi berbasis online menjadi poin penting dalam kajian ini. Atas dasar rasional di atas maka, tujuan dari artikel ini adalah untuk menelaah bagaimana dinamika pengemudi angkot dan mengetahui bagaimana adaptasi yang dilakukan oleh pengemudi angkot di kota 
Malang dalam menghadapi transportasi online.

\section{METODE}

Penelitian ini menggunakan metode kualitatif deskriptif. Fenomena yang dideskripsikan adalah kondisi pengemudi angkot pada masa sebelum dan setelah kemunculan transportasi berbasis online, serta mendeskripsikan bagaimana adaptasi pengemudi angkot di era transportasi berbasis online. Penelitian menggunakan sudut pandang kualitatif karena diperlukan kajian mendalam mengenai fenomena sosial yang terjadi, oleh karena itu diperlukannya penggalian data dari sudut pandang partisipan atau informan kunci, sehingga penelitian yang dilakukan dapat valid dan reliable (Sukmadinata, 2016; Nugrahani, 2014). Deskripsi dari penelitian ini bermanfaat untuk menjelaskan kepada pembaca mengenai fenomena secara rinci, dideskripsikan menggunakan kata-kata sehingga mudah untuk dipahami oleh pembaca.

Data penelitian diperoleh melalui kegiatan wawancara terhadap partisipan. Cara pemilihan partisipan menggunakan teknik snowball, dengan tujuan menghasilkan akumulasi data yang spesifik dari narasumber (Nurdiani, 2014). Teknik pengumpulan data menggunakan trianggulasi data melalui kegiatan observasi, wawancara, dan dokumentasi. Observasi dilakukan di terminal arjosari kota Malang, dengan waktu pelaksanaan 30 hari, peneliti mengamati bagaimana dinamika pengemudi angkot sesudah adanya pesaing transportasi berbasis online dan mengamati bagaimana adaptasi yang dilakukan setelah adanya transportasi berbasis online. Wawancara dilakukan kepada pengemudi angkot dan pengurus organisasi pengemudi di terminal arjosari dengan menggunakan instrumen pedoman wawancara.

Kegiatan pengumpulan data selanjutnya yaitu dokumentasi. Kegiatan dokumentasi dimaksudkan untuk memperoleh gambar dan foto mengenai kondisi pengemudi angkot dan armada angkot. Trayek yang dipilih oleh peneliti yaitu (1) Jurusan Arjosari-Dinoyo Landungsari yang merupakan jurusan rute Utara, (2) Jurusan Arjosari-MergosonoGadang yang merupakan jurusan rute Timur dan (3) Jurusan Arjosari-Landungsari yang merupakan jurusan rute tengah. Pemilihan trayek didasarkan kepada (1) Trayek jurusan ADL, AMG, AL Beroperasi di Kota Malang sesuai ruang lingkup penelitian, (2) Trayek melintasi lokasi-lokasi strategis seperti kantor, sekolah, dan kampus yang menjadi konsumen dari angkot (3) Wilayah Kota Malang juga terdapat banyak pengemudi transportasi berbasis online, sehingga menyebabkan persaingan baru dengan pengemudi angkot.

Analisis data menggunakan model interaktif dari Miles and Huberman yang terdiri dari 4 tahap pelaksanaan (Gambar 1), yaitu, (1) Pengumpulan data yang bertujuan mengumpulkan semua data yang diperoleh dari kegiatan observasi, wawancara, dan dokumentasi (Romadhoni, 2017), (2) Reduksi data, bertujuan untuk memilih dan merangkum hal-hal penting terkait data yang sudah diperoleh, kemudian data yang sudah direduksi telah disesuaikan dengan fokus kajian penelitian (Sugiyono, 2012), (3) Data yang sudah direduksi kemudian disajikan dalam bentuk (tabel, diagram, gambar, deskripsi singkat) dengan tujuan untuk memudahkan pemahaman terkait apa yang terjadi di lapangan (Hidayah, 2012), dan (4) Setelah data sudah fokus dan mudah untuk dipahami maka penarikan kesimpulan dapat dilakukan untuk menjawab permasalahan dasar yang diajukan dalam awal pembahasan artikel ini. 


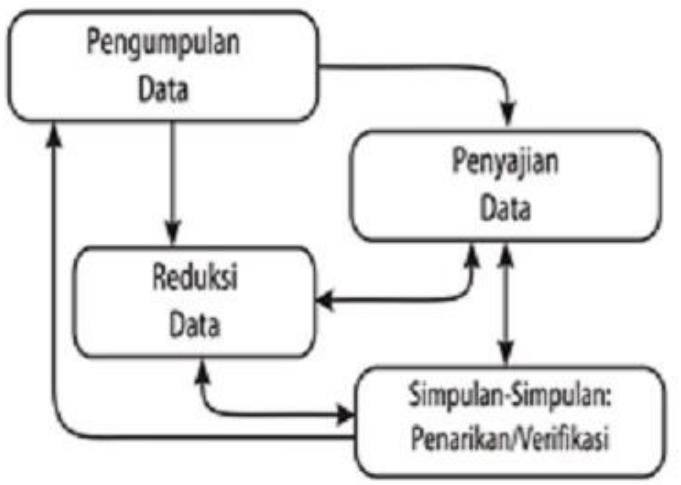

Gambar 1. Analisis model interaktif

Sumber: (Sugiyono, 2012)

\section{HASIL DAN PEMBAHASAN \\ Dinamika Pengemudi Angkot dalam Era Transportasi Online}

Bekerja sebagai pengemudi angkot merupakan jenis pekerjaan yang bergerak pada bidang jasa. Jenis pekerjaan ini bertujuan untuk, memberikan pelayanan kepada penumpang transportasi darat. Bekerja sebagai pengemudi angkot selain harus memiliki skill dalam berkendara, para pengemudi pun diharuskan memiliki kemampuan dalam hal berinteraksi dengan penumpang, karena pekerjaan ini mengutamakan pelayanan sebagai jual beli utama.

Pengemudi angkot di Kota Malang sebagai salah satu faktor yang mempermudah mobilitas masyarakat. Angkot sebagai angkutan kota resmi di kota Malang, sehingga keberadaannya sangat dibutuhkan. Pekerjaan pengemudi angkot sebelum 2016, dianggap sebagai salah satu pekerjaan primadona di masyarakat. $\mathrm{Hal}$ tersebut disebabkan karena, penghasilan yang sangat menjanjikan bahkan mengalahkan profesii seorang guru dan pekerja kantor.

Begitu vitalnya keberadaan pengemudi angkot di kota Malang, guna memenuhi kebutuhan masyarakat akan transportasi angkot, tercatat di kota Malang terdapat 25 rute perjalanan rutin (Malang, 2019). Beberapa rute memiliki nilai lebih tinggi, karena melewati pusat pendidikan dan pusat perbelanjaan, lokasi-lokasi tersebut sangat strategis karena menjadi pusat penumpang transportasi angkot.

Data pada Grafik 1 merupakan jumlah angkot yang aktif, sementara jumlah keseluruhan dari armada angkot di Kota Malang adalah 1667 unit. Penurunan ini salah satu hal yang menyebabkan yaitu dengan mulai beroperasinya transportasi berbasis online di kota Malang, sehingga banyak dari pengemudi angkot yang beralih profesi.

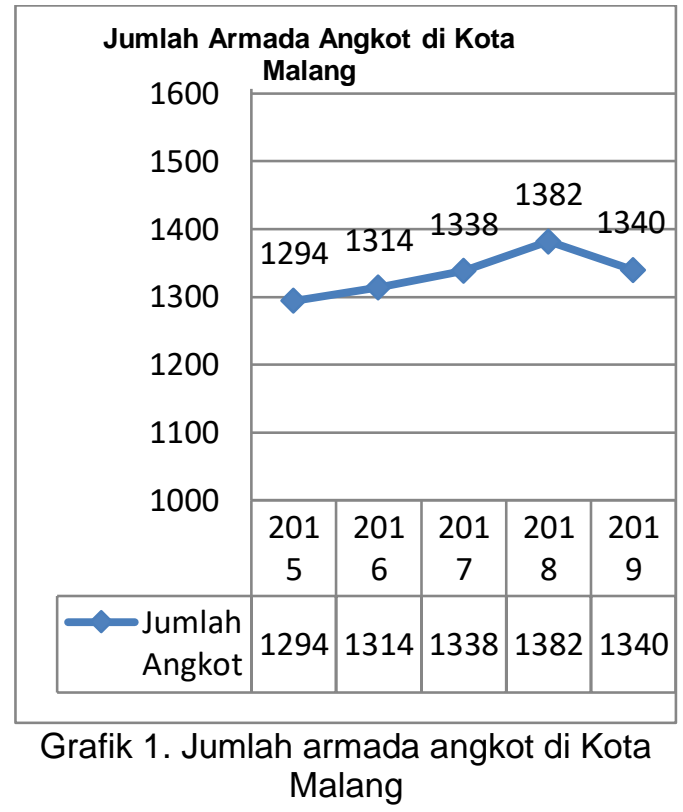

Pilihan untuk beralih profesi yang dilakukan pengemudi angkot, merupakan salah satu dinamika yang dirasakan, hal tersebut disebabkan karena adanya penurunan pendapatan pengemudi angkot. Berdasarkan hasil wawancara terhadap pengemudi angkot di Kota Malang, penghasilan rata-rata setiap hari sebelum munculnya transportasi berbais online berkisar Rp. 75.000-250.000 (lihat Grafik 2). Kondisi tersebut disumbang oleh pengguna transportasi public berupa golongan pelajar, pekerja pabrik, dan 
pegawai kantor. Mereka ingin mendapatkan layanan transportasi publik murah dan nyaman. Saat itu angkot menjadi pilihan yang paling memungkinkan karena jumlahnya yang banyak dan harga yang terjangkau.

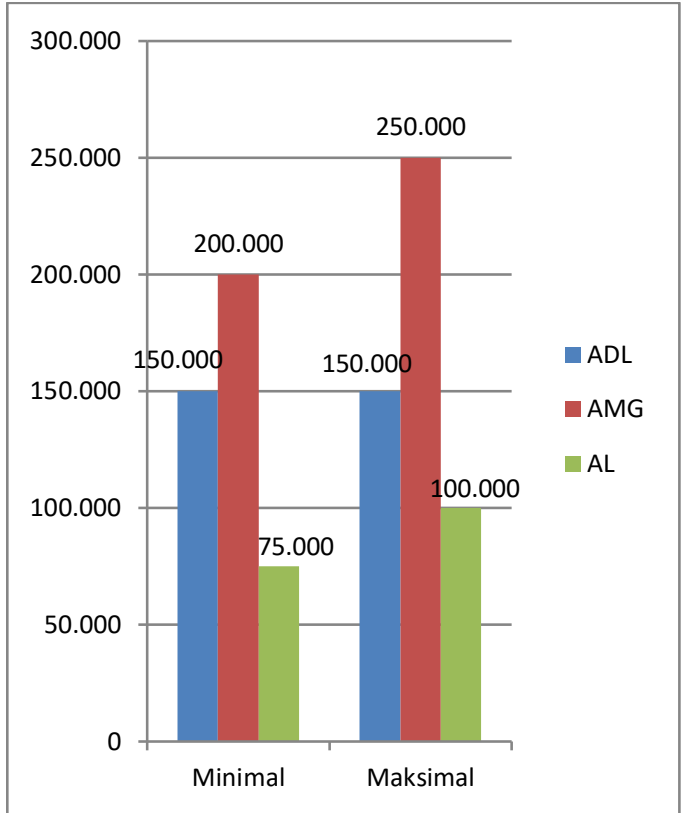

Grafik 2. Penghasilan pengemudi angkot sebelum adanya transportasi online

Penghasilan yang diperoleh pengemudi angkot tersebut diperoleh dari 5 kali pulang-pergi (PP). Namun seiring dengan perkembangan zaman yang semakin modern, hadirlah transportasi berbasis online. Sejak tahun 2016 transportasi berbasis online beroperasinya di wilayah Kota Malang. Transportasi ini menjadi pilihan baru masyarakat dalam menggunakan moda transportasi darat di Kota Malang. Dampaknya mereka menjadi pesaing angkot. Seperti yang diutarakan oleh pengemudi jurusan AMG (Gambar 2). Sebelum adanya transportasi online, trayeknya yang melalui lingkar timur Kota Malang bisa mendapatkan banyak penumpang di sekitar Malang Kota Lama.
Namun, semenjak adanya transportasi online, mengalami penurunan jumlah penumpang yang signifikan.

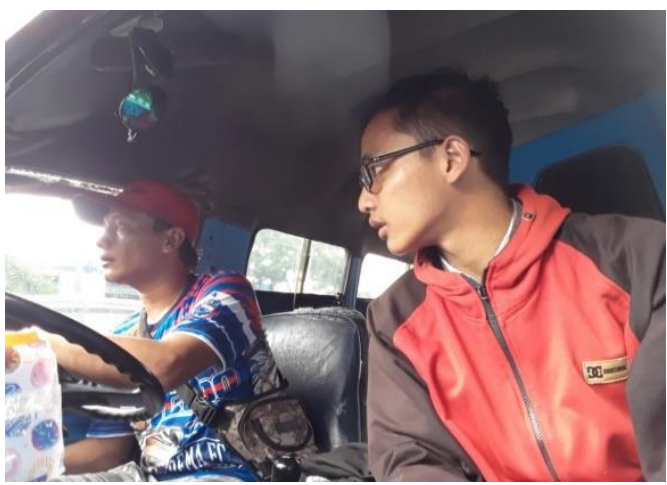

Gambar 2. Wawancara dengan pengemudi angkot jurusan AMG (2019)

Dokumentasi pribadi

Kehadiran transportasi online bagi pengemudi angkot, dianggap menjadi sebuah ancaman dan kompetitor baru. Adanya transportasi berbasis online menyebabkan penurunan jumlah penghasilan lihat Grafik 3).

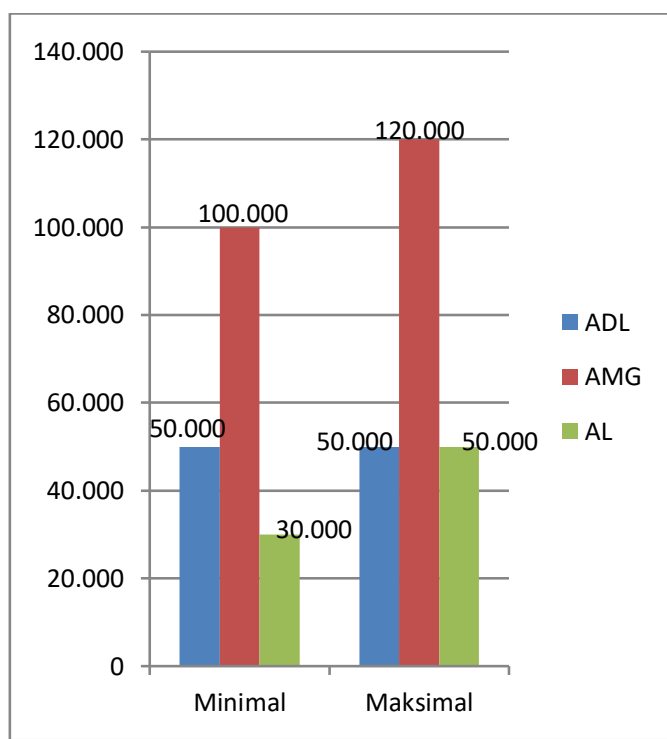

Grafik 3.Penghasilan pengemudi angkot sesudah adanya transportasi online

Jurnal IImu Sosial dan Humaniora | 255 
Seperti di kota malang pada jurusan AMG penghasilan pengemudi angkot berkisar 100.000 hingga 120.000 sedangkan untuk jurusan ADL berkisar 50.000, dan jurusan AL berkisar 35.000 hingga 50.000. ini menandakan bahwa penurunan penghasilan pengemudi angkot pasca adanya transportasi online rata-rata sebesar $>50 \%$.

Hal tersebut disebabkan karena kini dengan adanya transportasi berbasis online, menyebabkan penurunan jumlah penumpang transportasi angkot yang telah beralih menggunakan tranportasi berbasis online (Qisthi, 2018). Kini Para pengemudi angkot hanya dapat melakukan perjalanan 2-3 kali perjalanan PP. Penurunan jumlah perjalanan yang dilakukan oleh pengemudi angkot tidak berimbang dengan biaya operasional kendaraan. Karena tidak semua pengemudi angkot memiliki angkot sendiri melainkan, ada yang hanya menjadi buruh sehingga harus menyetor kan uang sekitar Rp. 50.000-70.000 per hari, selain itu ada biaya bensin yang harus dikeluarkan untuk sekali perjalanan pulang pergi yaitu sekitar Rp. 20.000-30.000.

Kondisi yang dialami pengemudi angkot karena adanya kompetitor baru disebut dengan Disruption Era. Disruption era memiliki arti sebagai era gangguan. Beberapa kalangan yang terganggu disebabkan karena seiring berkembangnya zaman maka, muncullah inovasi atau kebaharuan-kebaharuan sehingga secara perlahan sistem konvensional akan digantikan oleh sistem yang lebih modern (Darma, 2018). Disruption era yang terjadi salah satunya dirasakan pengemudi angkot. Sistem konvensional yang masih dijalankan oleh para pengemudi angkot dengan adanya transportasi online yang menggunakan sistem lebih modern, telah mengganggu terutama terhadap penghasilan pengemudi angkot.

Sejalan dengan hal tersebut salah satu transportasi umum yang menjadi pilih masyarakat kota Malang sebelum adanya transoortasi online yaitu Angkot.
Transportasi Angkot menjadi pilihan semua kalangan masyarakat kota Malang, hal ini disebabkan angkot sebagai angkutan kota yang resmi di kota malang serta biaya jasa yang dianggap murah, kisaran biaya untuk sekali perjalanan Rp. 2000-5000 sesuai dengan klasternya. Namun apabila penumpang membayar lebih dari harga yang telah ditetapkan, maka ada ongkos tambahan yang ditarik secara sepihak oleh pengemudi, terutama sering terjadi pada penumpang yang berangkat dari terminal.

Namun, setelah adanya transportasi online menjadi salah satu pilihan baru bagi masyarakat kota Malang. Sehingga penumpang dari angkot jauh menurun terutama kalangan pelajar, mahasiswa, dan pekerja kantor. Penurunan ini disebabkan kalangan pelajar dan mahasiswa merupakan kalangan yang kekinian dan disebut generasi millenial, sehingga lebih memilih transportasi online yang dianggap lebih praktis, modern, dan kekinian.

Jalur-jalur angkot di kota Malang, yang melewati pusat pendidikan menurun drastis jumlah penumpangnya seperti jalur $A L$ dan AD. Namun pada jalur angkot yang melewati pusat ekonomi tradisional seperti pasar besar, pasar combor penumpang masih relatif stabil pada jalur tersebut dilalui angkot jurusan AMG dan sejenisnya. Konsumen yang masih stabil tersebut disebabkan penumpang transportasi angkot, pada jalur tersebut yaitu kalangan orang tua seperti ibu-ibu, kakek, dan nenek. Pada kalangan ini lebih memilih transportasi angkot karena beberapa faktor, seperti: (1) biaya yang lebih murah, (2) sudah terbiasa menggunakan angkot sebagai transportasi pilihan utama, dan (3) tidak memiliki atau belum begitu memahami bagaimana penggunaan handphone android untuk memilih layanan transportasi.

\section{Adaptasi Pengemudi Angkot Dalam Menghadapi Transportasi Online}

Adanya transportasi berbasis online, membuat para pengemudi angkot harus melakukan adaptasi. Adaptasi dalam hal ini 
berkaitan dengan, usaha yang dilakukan untuk menghadapi keberadaan transportasi berbasis online, sehingga angkot tetap menjadi pilihan bagi masyarakat kota malang serta dapat bertahan di era transportasi berbasis online.

Berdasarkan kegiatan wawancara diketahui beberapa cara adaptasi yang dilakukan oleh pengemudi angkot dalam menghadapi era transportasi berbasis online, yaitu (1) peningkatan fasilitas, (2) peningkatan kualitas mengemudi, dan (3) layanan ketepatan waktu (lihat Gambar 3 a), b) ,dan c).

Memperbaiki fasilitas yang ada didalam angkot terkait dengan perbaikan tempat duduk, lampu penerangan, radio dan fasilitas lainnya guna meningkatkan kenyamanan pengguna. Cara mengemudikan angkot yang baik dan lebih berhati-hati, sehingga membuat pengguna tetap merasa aman serta ketepatan waktu berkaitan dengan mengurangi waktu menunggu penumpang (ngetime) hal tersebut membuat penumpang dapat tepat waktu dalam menjalani aktivitasnya.

Upaya perbaikan pelayanan yang dilakukan oleh pengemudi angkot. Baik dalam hal fasilitas ataupun pelayanan jasa. Bertujuan untuk menciptakan rasa nyaman dan aman bagi pengguna, harapannya dapat meningkatkan jumlah pengguna transportasi angkot. Karena dengan perbaikan atau peningkatan pelayanan transportasi terbukti dapat berpengaruh signifikan terhadap kepuasan dari pengguna (Semium, 2018).
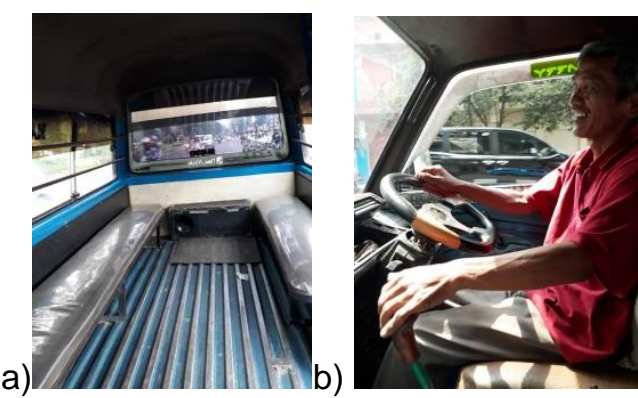

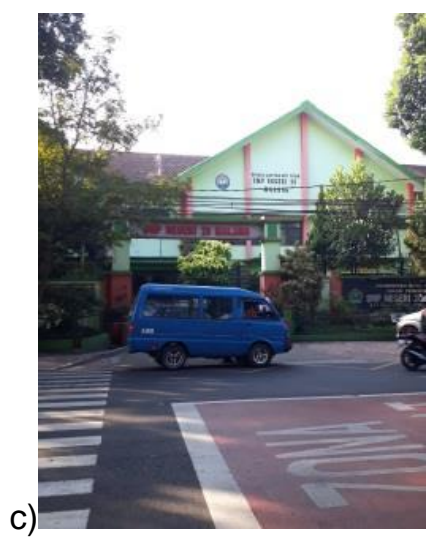

Gambar 3. a) Fasilitas dalam angkot; b) Cara mengemudi angkot; c) Ketepatan waktu menunggu anak pulang sekolah

Namun berdasarkan hasil wawancara diketahui bahwa, tidak semua pengemudi angkot sadar akan pentingnya adaptasi dalam menghadapi transportasi berbasis online. Pada kalangan pengemudi angkot ini tidak melakukan usaha perubahan guna memperbaikan pelayanan atau fasilitas angkot. Para pengemudi angkot lebih menyerahkan sepenuhnya kepada takdir dan tetap bersyukur dengan hasil yang telah diperoleh.

Keadaan pengemudi angkot tersebut disebabkan karena, faktor latar belakang yang kurang terampil dalam hal memperbaiki dan berinteraksi terhadap penumpang. Kemudian pengemudi angkot yang memiliki sifat kaku dalam melihat perkembangan transportasi.

Namun beberapa dari mereka tetap memiliki harapan, seperti: (1) angkot dibudayakan lagi, (2) kondisi ekonomi pengemudi angkot diperhatikan, meregulasi, dan (4) Memberikan kuota transportasi berbasis online di kota Malang. Harapan dari para pengemudi angkot tersebut bertujuan untuk, agar transportasi angkot dapat eksis di tengah berkembangnya zaman serta dengan pekerjaan sebagai pengemudi angkot dapat memperoleh penghasilan untuk memenuhi kebutuhan pribadi dan keluarga. 


\section{SIMPULAN DAN SARAN}

Bekerja sebagai pengemudi angkot di era modern menghadapi dinamika yaitu adanya transportasi berbasis online. Adanya kompetitor baru yang mengambil sebagian besar pengguna transportasi angkot, dampak yang dirasakan seperti, kegiatan operasional yang sebelum dilakukan sebanyak 5 kali PP sekarang menjadi 3 kali PP. Penurunan pendapatan yang dirasakan $50-150 \%$, penurunan drastis hingga $150 \%$ terutama dirasakan oleh pengemudi yang melewati wilayah perdagangan modern dan kampus. Sedangkan untuk pengemudi jalur malang kota lama yang melewati pasar tradisional penurunan yang dirasakan sekitar $50 \%$.

Adaptasi pengemudi angkot dalam menghadapi transportasi berbasis online. Upaya yang dilakukan memperbaiki fasilitas, memperbaiki cara mengemudi, dan menjaga ketepatan waktu. Adaptasi tersebut dilakukan untuk meningkatkan kepuasan pengguna sehingga transportasi angkot tetap eksis dan menjadi pilihan masyarakat Kota Malang. Namun tidak semua pengemudi sadar akan pentingnya adaptasi karena ada sebagian kalangan yang tidak melakukan adaptasi. Pada kalangan ini lebih mengutamakan takdir sehingga tidak melakukan usaha perbaikan.

Penurunan pengguna angkot di Kota Malang tidak hanya didasarkan pada banyaknya transportasi online. Rendahnya kualitas layanan mengakibatkan pengguna beralih ke moda trasportasi lainnya. Respon dari pengemudi angkot untuk meningkatkan layanan perlu didampingi oleh pemerintah baik dalam bentuk regulasi atau dukungan pinjaman dana lunak. Tujuannya adalah kesejahteraan hidup mereka tidak menurun.

\section{UCAPAN TERIMAKASIH}

Kami menyadari bahwasanya, dapat terselesainya artikel ini, karena mendapatkan dukungan, bimbingan, serta arahan dari berbagai pihak. Oleh itu kami mengucapkan terimakasih kepada:

1. Agus Purnomo, M.Pd, selaku dosen pembimbing yang telah meluangkan waktu dan tenaga untuk membimbing dan memberikan arahan.

2. Dinas Perhubungan Kota Malang

3. Bapak pengemudi angkot jurusan ADL, $A M G$, dan $A L$, yang telah bersedia menjadi informan penelitian ini.

4. Para Dosen dan Tendik Prodi Pendidikan IPS, yang telah memberikan ilmu dan pengalaman baik dalam bidang akademik atau nonakademik.

\section{DAFTAR PUSTAKA}

Anwar, A. A. (2017). Online vs Konvensional: Keunggulan dan Konflik Antar Moda Transportasi di Kota Makasar. Jurnal Etnografi Indonesia, 2(2), 220-246.

Darma, W. (2018). Inovasi Diskruptif (Disruptive Innovation) Dalam Pendidikan. Surakarta.

Hidayah, P. N. (2012). Analisis Faktorfaktor yang Mempengaruhi Keberhasilan Program Keluarga Berencana (KB) di Kecamatan Taktakan Kota Serang. In Skripsi. Serang.

Malang, D. K. (2019). Laporan Pendataan Jumlah Angkot Kota Malang. Malang: Dinas Perhubungan Kota Malang.

Muslimin. (2011). Perkembangan Teknologi dalam Industri Media. Jurnal Teknik Industri, 12(1), 57-64.

Nugrahani, F. (2014). Metode Penelitian Kualitatif dalam Penelitian Pendidikan Bahasa. Surakarta.

Nurdiani, N. (2014). Teknik Sampling Snowball Dalam Penelitian Lapangan. ComTech, 5(2), 11101118.

Nuryananda, P. F. (2017). Prospek Industri Teknologi Informasi dan Komunikasi dalam Perspektif Globalisme. Retrieved from 
https://www.academia.edu/117887

97/Prospek_Industri_Teknologi_Inf ormasi_dan_Komunikasi_dalam_P erspektif_Globalisme

Putranto, R. W. (2017). Strategi Adaptasi Dalam Menjaga Eksistensi Mikrolet (Studi Deskriptif Mengenai Strategi Adaptasi Dalam Menghadapi Persaingan Mikrolet di Kota Malang. Malang: Universitas Muhammadiah Malang.

Qisthi, F. A. (2018). Analisis Pendapatan Sopir Angkutan Kota (Angkot) di Kota Surakarta Serta Perbedaan Pendapatan Sebelum dan Sesudah Adanya Transportasi Daring (Online. Surakarta.

Rahayu, I. P. (2018, May). Transportasi Online dalam Pandangan Perkembangan Berkelanjutan (SDGs) dan Dampak Ekologi yang Ditimbulkan.

Romadhoni, F. (2017). Pola Komunikasi di Kalangan Pecandu Game LET'S GET RICH di Komunitas XLITE Tenggarong. eJournal IImu Komunikasi. fisip-unmul, 1(5), 235247.

Semium, O. E. (2018). Pengaruh Kualitas Pelayanan Angkutan Kota Terhadap Kepuasan dan Loyalitas Penumpang di Kota Kupang. Rekayasa Sipil, 39-49.

Sugiyono. (2012). Metode Penelitian Kuantitatif, Kualitatif dan R\&D. Bandung: Alfabeta, cv.

Sukmadinata, N. S. (2016). Metode Penelitian Pendidikan: Pendekatan Kuantitatif, Kualitatif, dan $R \& D$. Bandung: Alfabeta.

Sumut pos. (2018). Jumlah Angkot Tinggal 5000 Unit. Sumut pos.

Ticonuwu, M. V. (2018). Dampak Transportasi Online Terhadap Kesejahhteraan Supir Taxi Blue Brid di Kota. Repositori.usu.ic.id.

Utami, S. S. (2010). Pengaruh Teknologi Informasi dalam Perkembangan Bisnis. Jurnal Akuntansi dan
Sistem Teknologi Informasi, 8(1), 61-67.

Widyatami, F. S., \& Achmad Dzulfiqar Alfiansyah, H. S. (2016). Kajian Jumlah Armada Angkutan Kota Malang Berdasarkan SPM 2015 (Studi Kasus: Trayek $\mathrm{AH}<\mathrm{LDH}$ ADL). Jurnal Mahasiswa Teknik Sipil Universitas Brawijaya, 1(2). 